\title{
Meneguhkan Komitmen Menjadi Pelayan
}

Pada kegiatan reat-reat mahasiswa Teologi angkatan 2011, tim memilih tema di atas sebagai "Meneguhkan Komitmen menjadi Pelayan" karena terkesan sebagian besar mahasiswa Teologi saat ini tidak menampakkan komitmennya untuk menjadi pelayan. Pelayan dimaksud di sini terutama terkait keinginan sebagian besar mahasiswa untuk melayani sebagai Pendeta di jemaat. Sekalipun begitu dalam kenyataannya tidak semua mahasiswa yang belajar di Fakultas Teologi pada akhirnya akan menjadi Pendeta, ataupun guru PAK. Setelah tamat pendidikan ada yang memilih bekerja sebagai relawan kemanusiaan, ada yang bekerja pada instansi pemerintah, dan swasta. Ada pula mahasiswa yang harus di keluarkan ataupun keluar tanpa permisi karena berbagai sebab. Mereka inipun kemungkinan besar akan menekuni pekerjaan yang bersentuhan dengan pelayanan kepada orang lain. Dengan kata lain semua pekerjaan yang dilakukan oleh manusia selalu melibatkan orang lain di dalamnya.

Komitmen menurut Marcia dan Archer (1993) adalah keputusan terhadap pilihan (agama, bidang study, pekerjaan, teman hidup dll). Keputusan atas pilihan yang diambil perlu diupayakan sedemikian rupa agar tujuannya dapat dicapai. Menurut Klinger (dikutip oleh Frank, 2001) yang menyatakan bahwa komitmen adalah, seseorang yang benar-benar setia terhadap tujuannya, atau kuatnya usaha seseorang untuk mencapai tujuannya .

Keputusan mahasiswa yang memilih belajar di Fakultas Teologi dengan tujuan menjadi pelayan jemaat atau pendeta, ataupun menjadi pendidik merupakan komitmen. Berkaitan dengan tema yang dipilih kali ini, mungkin saja ada yang bertanya: mengapa komitmen tersebut harus diteguhkan, atau mengapa harus meneguhkan komitmen untuk menjadi pelayan?? Jawaban atas pertanyaan tersebut sebetulnya dapat dijawab oleh masing-masing mahasiswa sendiri. Jika mahasiswa merasa bahwa komitmennya mulai mengendor, ia mesti tahu apa yang harus dilakukan untuk memperkuat komitmen, demi mencapai tujuannya. Bagi tim pendamping reatreat kali ini, seperti yang telah dikatakan di atas bahwa kami mendapat kesan bahwa sebagian besar mahasiswa Teologi tidak memiliki komitmen yang kuat untuk mewujudkan tujuannya.

Pernyataan di atas, didasari pada realitas kehidupan mahasiswa yang tidak sejalan dengan cita-cita atau harapan bahwa mereka berkeinginan untuk menjadi pelayan atau pendeta dan pendidik. Hal tersebut dapat diamati melalui perilaku atau sikap dan kebiasaan-kebiasaan yang 
mengindikasikan lemahnya komitmen mereka. Padahal harapan atau cita-cita untuk menjadi pendeta atau pelayan dan pendidik mesti benar-benar diperjuangkan dengan sungguh-sungguh. Harapan atau cita-cita tidak dapat terwujud dengan sendirinya tanpa berkomitmen untuk menggapai atau menggenggamnya. Dalam kaitan itu, Hunter (1990) mengemukakan komitmen sebagai kesanggupan memberi diri atau mengikat diri dalam hubungan dengan melakukan sesuatu, atau untuk tujuan-tujuan tertentu dalam kehidupan. Menurutnya, konsep dasar teologis yang berkaitan dengan komitmen adalah perjanjian (covenant). Perjanjian dapat dikaitkan dengan panggilan (calling) untuk pekerjaan (vocation).

Bila dikaitkan dengan keputusan atau pilihan mahasiswa untuk dididik di Fakultas Teologi, dengan tujuan akan bekerja atau melayani sebagai pendeta dan pendidik atau guru. Keputusan atau pilihan tersebut berdasar pada alasan atau motivasinya yang sering diungkapkan dengan merasa terpanggil. Ungkapan merasa terpanggil dapat diartikan sebagai dorongan dari dalam diri untuk memenuhi harapan atau cita-citanya. Dalam hubungan itu, maka pengertian memberi diri atau mengikat diri dimengerti dalam konteks menerima pendidikan dan pembinaan yang dapat membentuk kemampuan dan ketrampilan baik dari segi akademik, spiritual, maupun ketrampilan praktis yang dibutuhkan sebagai persiapan untuk menjadi pendeta dan guru. Karenanya, dapat dikatakan komitmen menjadi pendeta, merupakan komitmen untuk menjunjung tinggi nilai-nilai moral dan etika yang mesti nyata dalam sikap dan perilaku mereka selama mengikuti proses pendidikan dan pembinaan.

Dari segi akademik nampak bahwa ada mahasiswa yang tidak mempersiapkan diri dengan baik ketika mengikuti kuliah. Tidak memasukkan tugas tepat waktu, menghindari pembahasan kelas dll. Dari segi spiritualitas, sebagian mahasiswa yang tidak mengindahkan jam-jam ibadah (malas bersekutu, sering sekali terlambat ke ibadah kampus, tidak menunjukkan sikap hormat terhadap sesama teman maupun dosen). Gambaran dari realitas akademik dan spiritualitas dapat dikemukakan dengan satu kata kunci yakni lemahnya kedisiplinan.

Disiplin adalah proses pemuridan (hal mengikuti Yesus Matius $8: 12$ - 22) Bila ditafsir secara bebas bagian nas ini, adalah bahwa disiplin merupakan hal yang sukar atau sulit,tapi tidak berarti tidak dapat dilakukan/dikerjakan. Kedisiplinan dapat dilakukan jika seseorang menyangkal diri untuk menuruti kesenangannya atau kemauan dirinya. Disiplin merupakan cara seseorang mengubah masa depannya menjadi lebih baik, dengan kata lain disiplin merupakan jalan orang meraih masa depan yang gemilang. Menurut pa Dekan dalam materi 
pembinaan disiplin diri, bahwa disiplin adalah perangkat dasar untuk memecahkan masalah kehidupan. Tanpa disiplin tidak ada masalah yang dapat dipecahkan. Tidak memecahkan masalah berarti menghambat pertumbuhan spiritualitas.

Dari aspek ketrampilan praktis yang dibutuhkan dari mahasiswa bukan saja ketrampilan dalam hal melakukan tugas-tugas belajar, tetapi juga terutama terampil dalam hal berperilaku. Yakni tahu menempatkan diri, sopan-santun dalam bertutur kata, juga dalam menyapa dan berpenampilan. Ketrampilan praktis dalam mengendalikan perilaku seperti dimaksud nampaknya mengendor. Contoh mahasiswa tidak menghargai sesama teman dan dosen yang sementara berkuliah, seenaknya berteriak dan ribut. Ruang kelas dijadikan tempat sampah dan asbak rokok. Padahal penampilan diri mahasiswa Teologi semestinya memperlihatkan bahwa mereka adalah calon-calon pemimpin jemaat/umat yang patut memberi teladan bagi mahasiswa fakultas lainnya di UKIM. Satu kata kunci untuk panampilan diri adalah menghargai diri sendiri.

Menghargai diri sendiri berarti sanggup menjaga sikap dan perilaku secara bijak karena menyadari bahwa sebagai mahasiswa Teologi patutlah menjadi model dalam bersikap dan berperilaku. Mahasiswa Teologi pantas menjadi model atau teladan bagi mahasiswa lainnya karena mereka memilih dididik untuk menjadi pendeta atau pelayan dan pendidik. Pilihan untuk menjadi pendeta/pelayan dan pendidik tidak sekedar berdasarkan pengamatan saja, tetapi memahami secara detail melalui pendidikan maupun latihan atau praktek yang berkaitan dengan bidang pekerjaan yang akan ditekuninya nanti. Keputusan untuk menetapkan pilihan disesuaikan dengan penilaian akan kemampuan dirinya atau merasa cocok dengan pilihannya. Selain itu juga penilaian terhadap gambaran nyata dari aktifitas pekerjaan yang akan dilaksanakannya. Jadi keputusan atas pilihan tersebut sekaligus merupakan komitmen dirinya. Jika dihubungkan dengan kemauan mahasiswa yang memilih belajar di Fakultas Teologi dengan tujuan akan bekerja atau melayani sebagai pendeta dan pendidik, maka pandangan dan perilaku mereka dibentuk melalui proses pendidikan dan pembinaan, agar lebih memperkuat motivasi dan komitmen mereka dalam rangka mencapai harapan atau tujuan mereka.

Meneguhkan komitmen untuk menjadi pelayan adalah tuntutan yang perlu diupayakan oleh mahasiswa Teologi untuk menggapai harapan atau tujuannya. Jika komitmen untuk menjadi pelayan tidak diteguhkan/dikuatkan, maka tidak mustahil komitmen tersebut akan dilepaskan. Menjadi pendeta/pelayan dan pendidik adalah pekerjaan yang mulia, karena melalui pekerjaan 
tersebut banyak orang akan menerima pelayanan dan dididikan. Menjadi pelayan dan pendidik pada hakekatnya menjadi orang-orang yang akan melayani orang lain. Hal ini berarti pelayan dan pendidik mestinya membentuk sikap dan perilaku yang rendah hati, tidak sombong, vulgar dan cuek. Untuk mencapainya mahasiswa tahu apa yang mesti mereka lakukan. S e m o g a !! 